\title{
AL-IQTISHADIYAH
}

Jurnal Ekonomi Syariah dan Hukum Ekonomi Syariah

E-ISSN: 2621-0274; P-ISSN: 2442-2282

Volume 7, Nomor 2, Desember 2021

\section{Analisis Strategi Pengembangan Pariwisata Pada Masa Pandemi Covid-19 Di Agro Belimbing Moyoketen Tulungagung}

\section{Devi Nindya Nur Anugraheni ${ }^{1} \&$ Sri Eka Astutiningsih ${ }^{2}$}

1 Fakultas Ekonomi dan Bisnis Islam, Universitas Islam Negeri Sayyid Ali Rahmatullah, Tulungagung, Indonesia. E-mail: devinindyyaa@gmail.com

2 Fakultas Ekonomi dan Bisnis Islam, Universitas Islam Negeri Sayyid Ali Rahmatullah, Tulungagung, Indonesia. E-mail: srieka_astutininggsih@yahoo.com

\section{ARTICLE INFO}

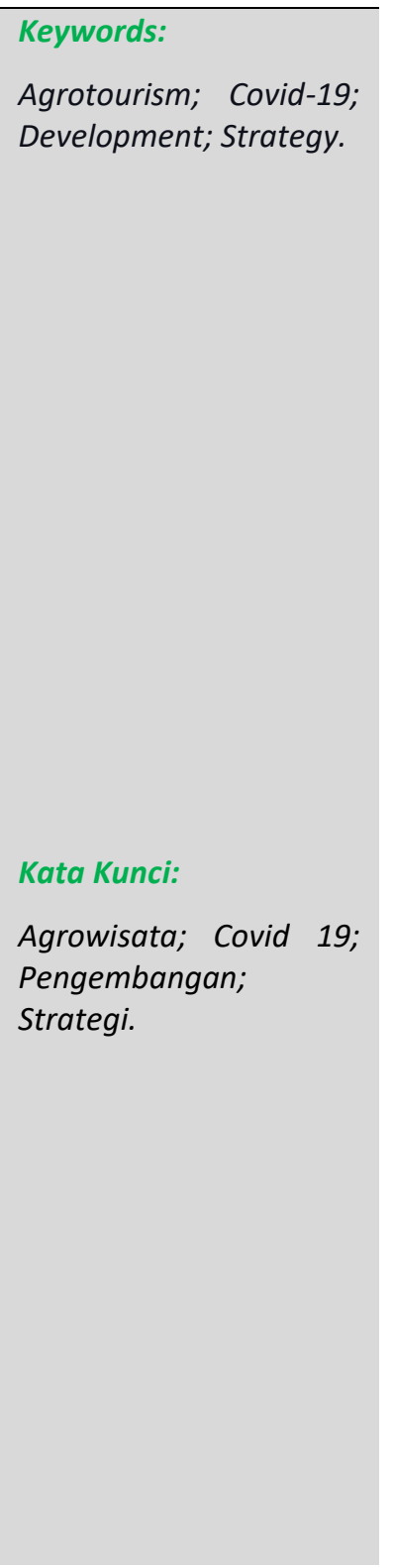

\section{ABSTRACT}

This research is supported by the tourim that attractive and develop well nowdays. We need to develop the tourism well to be interested. One of the place that showes the beautiful of plantation, nature, and education of starfruit tourism is Starfruit. The problem and objective research are the strategy, the constraint, and the effort of the management faced during the Covid-19 pandemic. This study uses a qualitative approach while the data is taken from the method of observation, interviews, and documentation and the application using SWOT analysis. The results of this study indicate that we need to use information media to promote agro-tourism through various social media, especially during the Covid-19 pandemic, cause many people are actively online. Furthermore, the formulation of strategies used in the management of starfruit agrotourism faced by Covid-19 pandemic which affects the course of tourism by considering various external organizational factors including opportunities, namely Moyoketen Boyolangu Tulungagung agrotourism which has a location and road access that is easy to pass and find my community, so that it can be used to build various tourist areas.

\section{ABSTRAK}

Penelitian ini di latar belakangi oleh perkembangan pariwisata saat ini semakin pesat. Untuk membangun sebuah pariwisata yang menarik perlu dilakukan pengembangan yang baik. Satu di antara tempat wisata yang mengunggulkan keindahan alam perkebunan dan wisata edukasi seputar buah belimbing disebut dengan agrowisata belimbing. Rumusan masalah dan tujuan dalam penelitian ini adalah strategi yang dilakukan oleh pengelola di Agrowisata Bielimbing Desa Moyoketen Kabupaten Tulungagung di masa pandemi Covid-19, kendala yang dihadapi oleh pengelola dan upaya yang sudah dilakukan di masa pandemi Covid-19. Penelitian ini menggunakan pendekatan secara kualitatif. Sedangkan data yang diambil adalah menggunakan method observasi, wawancara, dan dokumentasi. Dengan menggunakan analisis SWOT. Hasil penelitian ini menunjukkan bahwamemanfaatkan media informasi untuk melakukan promosi agrowisata melalui berbagai media sosial apalagi dimasa pandemi Covid-19 banyak masyarakat yang beraktivitas secara online. Selanjutnya formulasi strategi yang dilakukan dalam 
pengelolaan agrowisata petik belimbing dalam menghadapi pandemi Covid-19 yang berpengaruh pada jalannya wisata dengan mempertimbangkan berbagai faktor eksternal organisasi diantaranya opportunities (peluang) yaitu agrowisata Moyoketen Boyolangu Tulungagung yang memiliki lokasi dan akses jalan yang mudah untuk dilalui dan ditemukan oleh masyarakat, sehingga dapat dimanfaatkan untuk membangun kawasan wisata yang bervariasi.

\section{Pendahuluan}

Perkembangan pariwisata di Indonesia saat ini semakin pesat. Dengan berkembangnya pariwisata yang terpenting adalah pengembangan dalam bidang ekonomi. Pariwisata memiliki potensi yang layak untuk dikelola dan salah satu sektor yang wajib dikembangkan secara maksimal dari sumber daya yang ada. ${ }^{1}$ Dan kepariwisataan termasuk satu diantara sektor pembangunan yang diharapkan dapat menjangka laju pemerataan dalam sektor peningkatan ekonomi Indonesia, melalui beragam aspek yang tercantum di dalamnya seperti penerimaan devisa, pemerataan pendapatan ekonomi rakyat, memperluas kesemapatan kerja dan apalagi pariwisata saat ini dibebani pula satu pendekatan ekonomi dengan ikut serta mengentaskan kemiskian. ${ }^{2}$ Pariwisata di Indonesia sangat unggul dan maju dikarenakan di Indonesia itu sendiri memiliki banyak tempat serta adat dan budaya juga tradis yang dapat dijadikan sebagai daya tarik wisatawan atau pengunjung.

Menurut UU. No. 9 Tahun 1990 Pasal 1 dikutip oleh Oka A. Yoeti pariwisata yaitu segala obyek yang memiliki hubungan dengan wisata, seperti keterampilan obyek dan daya tarik wisata serta cara yang ada kaitannya terhadap penyelenggaraan pariwisata. ${ }^{3}$ Dalam pengembangan sektor pariwisata ada harapan agar dapat menunjang bagaimana cara melestarikan alam, keaneragaman hayati dan budaya bangsa. Atraksi wisata dan daya tarik wisata sangat memberi pengaruh dalam bidang kemajuan perindustrian pariwisata. Sesuatu yang dipersiapkan terlebih dahulu agar dapat dilihat, dinikmati dan termasuk dalam hal ini yaitu tari-tarian, kesenian rakyat tradisonal, upacara adat dan lain sebagainya disebut dengan atraksi wisata. Sedangkan daya tarik wisata yaitu suatu yang mempunyai keunikan, keunggulan, dan memegang kualitas tinggi yang menjadi sasaran dan tujuan kunjungan wisatawan. ${ }^{4}$

Dalam membangunan sebuah tempat wisata yang tidak disertai dengan usaha perencanaan, pengelolaan dan pengoperasian penguasaan yang kurang maksimal menjadi kendala untuk para pengelola dalam mengarahkan tujuan dalam mendirikan

\footnotetext{
${ }^{1}$ Anita Sulistiyaning Gunawan, Maria Goretti, dan Wi Endang, "Analisis Pengembangan Pariwisata Terhadap Sosial Ekonomi Masyararakat," Jurnal Administrasi Bisnis (JAB) 32, no. 1 (2016): 2.

${ }^{2}$ Wahyu Prihanta, Amir Syarifuddin, dan Ach. Muhib Zainuri, "Pembentukan Kawasan Ekonomi Melalui Pengembangan Ekowisata Berbasis Masyarakat," Jurnal Dedikasi 14 (2017): 73-84.

${ }^{3}$ Eri Besra, "Potensi Wisata Kuliner Dalam Mendukung Pariwisata Di Kota Padang," Jurnal Riset Akuntansi dan Bisnis 12, no. 1 (2021): 11.

${ }^{4}$ Kepariwisataan, "Undang-undang Republik Indonesia No 10 Tahun 2009 Tentang Kepariwisataan Pasal 1 ayat 5," 2009.
} 
wisata tersebut, karena itu bisa menghambat dalam proses pengembangan tempat wisata itu sendiri. Seperti minimnya kedatangan wisatawan dikarenakan masih terbatas pembangunan destinasi wisata dan objek wisata, masalah ini akan mengakibatkan menurunnya pendapatan yang didapat pihak pengelola wisata.

Wabah global yang berdampak buruk pada dimensi manusia dan sosial disebut covid 19. Virus ini setelah meluas dari China, akhirnya pandemi menyebar begitu cepat ke 210 negara termasuk Indonesia. Bagai mimpi buruk pandemi Covid-19 untuk ekonomi global. Ekonomi mengalami penurunan dari satu tahun yang lalu dan mungkin lebih lama jika tindakan penahanan wabah Covid-19 tidak efektif. ${ }^{5}$ Dimasa transisi atau pandemi Covid-19 telah berdampak terhadap berbagai bidang dalam aktivitas manusia terutama di sektor periwisata. Tidak adanya kunjungan para wisatawan yang menyebabkan tempat pariwisata ditutup, dan itu berdampak pada penurunan dalam pengembangan sektor pariwisata. Salah satunya berdampak di Agro Belimbing Desa Moyoketen Kecamatan Boyolangu Kabupaten Tulungagung.

Di Kabupaten Tulungagung memiliki banyak tempat wisata salah satunya yaitu Agrowisata Belimbing Moyoketen Tulungagung yang saat ini ramai wisatawan yang berkunjung. Agrowisata Belimbing merupakan salah satu di antara tempat wisata yang mengunggulkan keelokan lingkungan perkebunan dan wisata edukasi terkait buah belimbing dari sejarahnya sampai meluas ke seluruh Indonesia. Akibat adanya pandemi Covid-19 ini Agrowisata Belimbing Moyoketen Tulungagung mengalami jumlah penurunan pendapatan dan wisatawan. Agrowisata Belimbing Moyoketen Tulungagung, tepatnya beralamat di Dsn Pacet Ds. Moyoketen RT. 003 RW. 004. Kecamatan Boyolangu Kabupaten Tulungagung.

Gambar 1. Peta Lokasi Penelitian di Kawasan Agrowisata Belimbing Desa Moyoketen

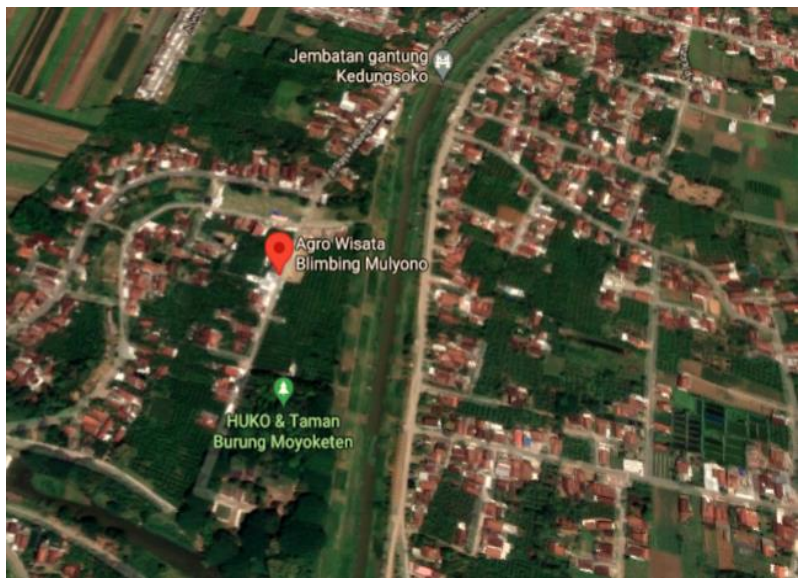

Sumber: Google Maps, 2021

Bapak Mulyono, salah satu pengelola Agrowisata Belimbing Moyoketen Tulungagung. Banyak pohon belimbing yang mengelilingi pekarangannya yang sangat luas, bernuansa alami, dan asri membuat wisatawan merasa santai menikmatinya. Sudah

\footnotetext{
${ }^{5}$ Tety Eka Oktaviyani, “Analisis Strategi Pemasaran Terhadap Pengelolaan Wisata Telaga Sarangan Di Kabupaten Magetan" (Institut Agama Islam Negeri Ponorogo, 2020), 8.
} 
sejak tahun 1992 kebun belimbing berdiri dan akhirnya sekarang berkembang menjadi tempat wisata edukasi Agrowisata Belimbing yang mempunyai nilai edukasi dan estetika tinggi.

Sebagaimana penelitian yang dilakukan oleh Hakkiatul Lutpi Hakkiatul Lutpi (2016), dengan judul "Analisis Tingkat Partisipasi Masyarakat Dalam Pengembangan Pariwisata Pantai Di Kecamatan Jerwaru". Penelitian ini bertujuan untuk mengetahui tingkat partisipasi masyarakat dalam pengembangan pariwisata pantai, dan upaya pemerintah untuk meningkatkan partisipasi masyarakat dalam mengembangkan pariwisata pariwisata pantai di Kecamatan Jerowaru. Hasil penelitian menunjukkan bahwa tingkat partisipasi masyarakat dalam pengembangan pariwisata pantai di Kecamatan Jerowaru masih rendah, terlihat dari nilai/skor terhadap keseluruhan dari keempat indikator yang digunakan yaitu sebesar 0,89 . Upaya pemerintah untuk meningkatkan partisipasi masyarakat dalam pengembangan pariwisata pantai adalah dengan membuat progam kelompok sadar wisata (jambore pokdarwis), dan berupaya melakukan pembangunan fisik pariwisata seperti sarana dan prasarana pariwisata. ${ }^{6}$

Penelitian oleh Hugo Itamar(2014), dengan judul "Strategi Pengembangan Pariwisata di Kabupaten Tana Toraja". Tujuan penelitian ini adalah untuk mengetahui apa saja faktor yang kemudian mempengaruhi dalam pengembangan pariwisata di Tana Toraja.hasil penelitian menunjukkan bahwa ada 7 strategi yang digunakan yakni strategi dasar yang bersifat multiplier effect, strategi terkait dengan pengelolaan interset pariwisata, strategi keterkaitan dan pengembangan produk, strategi pemantapan pemasaran, strategi pengembangan sumber saya manusia, strategi spasial pengebangan wisata, strategi pengembangan pariwisata bidang distribusi. Dimana dari 7 strategi ini telah dilaksanakan dalam waktu 2011-2016. Akan tetapi ada strategi yang belum berjalan maksimal sehingga hasil yang diinginkan belum tercapai dengan baik. Kemudian alam, budaya, masyarakat, objek wisata, dan promosi pasar wisata menjadi pendukung pariwisata Tana Toraja. Akses jalan, sarana, sumber daya manusia, peraturan dan landasan hukum, pengelolaan objek wisata, menjadi faktor penghambat jalannya pelaksanaan startegi pengembangan pariwisata di Kabupaten Tana Toraja. ${ }^{7}$

Penelitian yang dilakukan oleh Abdul kadir Jaelani (2018) dengan judul "Pengembangan Destinasi aiwisata halal Pada Era Otonomi Luas di provinsi nusa tenggara Barat". Penelitian ini bertujuan untuk mengetahui dan menganalisis latar belakang lahirnya pengembangan pariwisata halal di Provinsi Nusa Tenggara Barat dan kendala yang dialami dalam melaksanakan Perda pariwisata halal serta upaya yang dilakukan oleh Pemda tersebut. Hasil penelitian menunjukkan bahwa, latar belakang lahirnya Perda tentang pariwisata halal di Provinsi Nusa Tenggara Barat berlandaskan pada tiga hal yaitu pertama, landasan filosofinya adalah pembangunan di bidang

\footnotetext{
6 Hakkiatul Lutpi, "ANALISIS TINGKAT PARTISIPASI MASYARAKAT DALAM PENGEMBANGAN PARIWISATA PANTAI DI KECAMATAN JEROWARU," Jurnal Program Studi Pendidikan Ekonomi 8, no. 3 (2016): 1-10.

7 Hugo Itamar, "Strategi Pengembangan Pariwisata di Kabupaten Tana Toraja," Jurnal IImu Pemerintahan 7, no. 2 (2014): 91-108.
} 
ekonomi dalam rangka mendukung terwujudnya percepatan kesejahteraan masyarakat, pemerataan kesempatan berusaha, memperoleh manfaat dan mampu menghadapi tantangan perubahan kehidupan dengan tetap memperhatikan sistem nilai budaya yang berlaku di masyarakat sesuai dengan nailai-nilai luhur pancasila. Kedua, landasan sosiologis pengembangan pariwisata halal adalah aspek demografis dan geografis Provinsi Nusa Tenggara Barat sangat menunjang pelaksanaan pariwisata. ${ }^{8}$

Dari uraian yang dipaparkan diatas maka timbul permasalahan yang ada, untuk menanggulinya yaitu seperti penerapan yang sesuai dengan strategi pengembangan. Karena di masa pandemi Covid-19 sekarang ini upaya dalam mengembalikan kestabilan perekonomian sangat penting dilakukan. Mengingat pentingnya pengembangan pariwisata di Agrowisata Belimbing Moyoketen Boyolangu Tulungagung sebagai tempat wisata edukasi dilihat dari permasalahannya maka penelitian ini dilakukan untuk mengetahui kendala yang dihadapi oleh pengelola dimasa pandemi Covid-19 dan untuk mengetahui strategi terkait dengan pengembangan pariwisata di masa pandemi Covid-19.

\section{Kajian teori}

\section{Strategi Pengembangan}

Strategi menurut Kenneth R. Adrews, ialah suatu proses dalam mengevaluasi kekuatan dan kelemahan yang dibandingkan dengan peluang dan ancaman untuk memutuskan strategi pasar di dalam lingkungan yang ada untuk menyesuaikan kemampuan perusahaan. ${ }^{9}$ Sedangkan Hamel dan Prahalad mengutarakan bahwa strategi adalah tindakan seseorang yang bersifat incremental (senantiasa meningkat) dan terus-menerus, serta dilakukan sesuai sudut pandang tentang apa yang diharapkan oleh para pelanggan di masa depan. ${ }^{10}$

Dari pengertian di atas dapat disimpulkan strategi merupakan suatu proses yang direncanakan untuk mencapai sasaran perusahan dalam jangka waktu panjang. Di saat strategi tersebut sudah terealisasikan maka akan dapat diketahui apakah strategi itu berhasil atau gagal.

Strategi pengembangan yaitu suatu cara yang terencana dan terus-menerus dalam menerapkan pengetahuan karakter untuk mengembangkan sistem dengan memanfaatkan method dan analisis diri. ${ }^{11}$ Strategi yang digunakan untuk tempat menuju sebuah proses perubahan terencana yang maksimal memerlukan dukungan dari semua pihak, baik itu dari pihak pengelola maupun karyawan.

\footnotetext{
${ }^{8}$ Abdul Kadir Jaelani, "Pengembangan Destinasi Pariwisata Halal Pada Era Otonomi Luas di Provinsi Nusa Tenggara Barat," Jurnal Pariwisata 5, no. 1 (2018): 56-67.

${ }^{9}$ Panji Anoraga, Manajemen Bisnis (Jakarta: Rineka Cipta, 2004), 338-39.

${ }^{10}$ Sesra Budio, “Strategi Manajemen Sekolah," Jurnal Menata 2, no. 2 (2019): 56-72.

${ }^{11}$ Umar Nimran, Perilaku Organisasi (Surabaya: Citra Media, 1997), 109.
} 
Dengan demikian perubahan tersebut diharapkan dapat meningkatkan dan mengembangkan suatu perusahaan. Baik usaha jangka pendek, menengah, dan jangka panjang untuk menghadapi perubahan yang terjadi dimasa mendatang, hal tersebut disebut strategi pengembangan.

Hisyam Alie menyatakan, strategis yaitu suatu penerapan strategi jika menginginkan hasil yang maksimal, maka perlu dilakukannya penyusunan, konsentrasi dan konsep secara efektif. Menurut beliau, untuk dapat mencapai strategi yang strategis wajib memperhatikan hal-hal berikut: ${ }^{12}$

a. Kekuatan, yang biasanya menyangkut manusia dan dana.

b. Kelemahan, ialah kelemahan yang memperhitungkan dan menyangkut beberapa aspek sebagai kekuatan.

c. Peluang, ialah cara untuk mengungkap pengetahuan atau kepercayaan bahwa suatu kejadian akan terjadi.

d. Ancaman, ialah memperhitungkan kemungkinan yang akan terjadi dari luar.

\section{Pariwisata}

Secara teknis pariwisata ialah rangkaian kegiatan yang melibatkan seseorang baik perorangan maupun kelompok, bisa di negara sendiri ataupun di negara lain. Kegiatan tersebut menggunakan kemudahan, jasa dan faktor penunjang lain yang diadakan oleh pemerintah atau oleh masyarakat setempat guna mewujudkan keinginan para wisatawan. ${ }^{13}$ Pengertian pariwisata itu sendiri memiliki hubungan erat dengan perjalanan wisata, yang memiliki arti sebagai suatu perubahan, atau bisa dikatakan oleh seseorang maupun kelompok orang dengan mengunjungi tempat tertentu untuk tujuan rekreasi atau mengeksplorasi daya tarik wisata dalam waktu sementara.

Sedangkan pengertian dari pengembangan pariwisata yaitu suatu usaha untuk mengembangkan atau memajukan objek wisata tersebut agar lebih baik dan lebih menarik dilihat dari segi tempat maupun benda-benda yang ada di dalamnya agar dapat menarik minat wisatawan untuk mengunjunginya.

\section{Agrowisata}

Pemanfaatan usaha pertanian (agro) sebagai objek wisata yang didasari untuk tujuan memperluas pengetahuan, pengalaman wisata yang berhubungan dengan usaha di sektor pertanian. Istilah lain dari agrowisata yaitu kegiatan atau wisata yang mengacu pada kegiatan melakukan kunjungan kepada petani yang sedang bekerja di lahan pertanian mereka, dengan kata lain wisatawan akan melihat-lihat para petani dalam memproses pembibitan, penanaman, pemanenan, dan kegiatan

\footnotetext{
12 Rafi?

${ }^{13}$ Hari Karyono, Kepariwisataan (Jakarta: PT. Remaja Rosdakarya, 1997), 15.
} 
pengelolaan produk pertanian menjadi produk olahan dalam konteks kegiatan agrobisnis. $^{14}$

Dalam strategi pengembangan agrowisata secara garis besar meliputi beberapa aspek seperti sumber daya manusia, sumber daya alam dan promosi. Usaha pengembangan agrowisata ini bukan hanya bisa menikmati sumber daya alam akan tetapi wisatawan juga bisa menikmati indahnya perkebunan atau bisa menikmati beraneka ragam atraksi spesifik yang dilakukan oleh masyarakat yang dapat diunggulkan, akan tetapi tetap menjaga estetika masyarakat lokal yang ada, sehingga dapat menghasilkan produk yang baik.

Dalam mengembangkan agrowisata ada beberapa orang yang berperan penting yaitu pengelola, pengunjung atau wisatawan, dan pemerintah atau institusi. Kawasan agrowisata merupakan suatu kawasan yang memiliki kriteria sebagai berikut: ${ }^{15}$

a. Memiliki potensi atau basis kawasan di sektor agro baik pertanian, hortikultura, perikanan maupun peternakan

b. Adanya kegiatan masyarakat yang didominasi oleh kegiatan pertanian dan wisata dengan keterkaitan dan ketergantungan yang cukup tinggi. Kegiatan pertanian yang mendorong tumbuhnya industri pariwisata, dan sebaliknya kegiatan pariwisata yang memacu berkembangnya sektor agro.

c. Adanya interaksi yang intensif dan saling mendukung bagi kegiatan agro dengan kegiatan pariwisata dalam kesatuan kawasan. Berbagai kegiatan dan produk wisata dapat dikembangkan secara berkelanjutan.

\section{Metode Penelitian}

Dalam melakukan penelitian, peneliti memilih lokasi penelitian yaitu tempat wisata edukasi di Agro Belimbing Moyoketen Tulungagung. Penetapan lokasi penelitian terkait dengan tema penelitian yakni pengembangan pariwisata berkelanjutan. Dalam penelitian ini berusaha untuk mengkaji bagaimana dampak strategi pengembangan Agro Belimbing di Desa Moyoketen Tulungagung dimasa pandemi Covid-19 dan menguraikan potensi yang ada di daerah tujuan seperti potensi fisik maupun non fisik sebagai obyek wisata berkelanjutan.

Penelitian ini menggunakan studi kasus yang merupakan salah satu fase dari method kualitatif yang membahas suatu kasus secara mendalam, dengan mengumpulkan beberapa informasi dari para informan. ${ }^{16}$ Informan dalam penelitian ini yaitu satu

\footnotetext{
${ }^{14}$ Desna Kurniati, “Potensi Pengembangan Agrowisata Sebagai Kawasan Eduwisata Lokal Di Agrowisata Cilangkap Jakarta Timur" (universitas Islam Negeri Syarif Hidayatullah Jakarta, 2015), 10.

${ }^{15}$ Direktorat Pengembangan Kawasan Khusus dan Tertinggal, Tata Cara Perencanaan Pengembangan Kawasa untuk Percepatan Pembangunan Daerah (Bappenas, 2004).

${ }^{16}$ J.R Raco, Metode Penelitian Kualitatif Jenis, Karakteristik dan Keunggulannya (Jakarta: Grasindo, 2013).
} 
pemilik agrowisata belimbing Moyoketen dan dua karyawan agrowisata belimbing Moyoketen. Sumber data yang digunakan ialah sumber data primer dan sumber data sekunder. Dalam teknik pengumpulan data kualitatif yang digunakan oleh peneliti yaitu metode observasi, metode wawancara atau interview dan dokumentasi dengan menggunakan teknik analisis data reduksi data, penyajian data, dan penarikan kesimpulan.

Selanjutnya analisis penelitian ini dengan menggunakan analisis SWOT. Analisis SWOT digunakan untuk dapat mengetahui masalah, kelemahan, ancaman, peluang Agrowisata Belimbing Moyoketen Tulungagung, membuat rumusan strategi untuk kebijakan optimalisasi Agrowisata Belimbing Moyoketen Tulungagng yang berdampak terhadap peningkatan ekonomi masyarakat kelompok tani, serta keberlanjutan agrowisata. SWOT adalah suatu instrumen yang mengindentifikan bermacam-macam faktor yang mem-bentuk secara sistematis untuk dapat digunakan dalam merumuskan strategi perusahaan. ${ }^{17}$ Pengertian analisis SWOT adalah suatu teknik analisis terhadap faktor-faktor internal (Strengths, Weaknesses) dan eksternal (Opportunities, Threats). ${ }^{18}$ Analisis ini digunakan untuk merumuskan strategi pengembangan yang cocok dalam mengoptimalkan dan mengembangkan Agrowiata Belimbing Moyoketen Telungagung dalam meningkatkan ekonomi masyarakat sekitar Desa Moyoketen Kecamatan Boyolangu Kabupaten Tulungagung.

\section{Hasil dan Pembahasan}

Dalam upaya pengembangan potensi pariwisata diperlukan adanya pengelolaan yang strategis serta bertahap demi tercapainya tujuan. Sesuai dengan teori Marpaung yang menyatakan bahwa strategi menimbulkan suatu komitmen bagi organisasi yang bersangkutan kepada tindakan-tindakan mengarah pada masa depan. Selanjutnya, Manajemen strategi pada pariwisata umumnya memiliki konsep untuk melihat setiap fakta demi tercapainya tujuan jangka panjang. ${ }^{19}$ Dan juga pada penelitian yang dilakukan oleh Evi Fitriana ${ }^{20}$ dengan hasil penelitian yaitu membangun sarana dan prasarana seperti alat angkut dan sarana akomodasi, yang telah melibatkan pemerintah dan instansi lainnya dalam pengelolaan wisata tersebut.

Peran manajemen strategis yang sedikit kompleks sangat mem-pengaruhi perjalanan sebuah program untuk mendapatkan hasil yang telah ditetapkan dan direncanakan sebelumnya. Manajemen strategis berfokus pada tindakan yang mengarahkan sebuah

\footnotetext{
${ }^{17}$ Fajar Nur?aini, Teknik Analisis Swot (Jakarta: Anak Hebat Indonesia, 2016), 8.

18 Muhammad Rifqi Hidayat, Rusdiana Rusdiana, dan Parman Komarudin, "Strategi Pendidikan Kewirausahaan Di Sekolah Dasar Alam Muhammadiyah Banjarbaru," AdBispreneur : Jurnal Pemikiran dan Penelitian Administrasi Bisnis dan Kewirausahaan 6, no. 2 (23 November 2021): 131, https://doi.org/10.24198/adbispreneur.v6i2.31144.

${ }^{19}$ L. I. Centre, “Econstor," 2011.

${ }^{20}$ Evi Fitriana, "Strategi Pengembangan Taman Wisata Kum Kum Sebagai Wisata Edukasi Di Kota Palangkaraya," Jurnal Pendidikan Geografi 23, no. 2 (2018): 102.
} 
organisasi dalam menghadapi tantangan agar dapat bertahan dimasa depan sesuai dengan visi misi serta tujuan yang telah ditentukan oleh organisasi.Langkah dalam mempersiapkan manajemen strategi yang dilakukan Agro Belimbing Moyoketen, Tulungagung termasuk dengan menyamakan strategi dengan visi misi yang ada untuk digunakan sebagai landasan dalam memperhitungkan segala hal dalam perencananaan, termasuk aspek peristiwa dan perubahan yang bisa terjadi di masa depan yang dapat mempengaruhi secara langsung maupun tidak langsung proses jalannya Desa Agrowisata petik belimbing ini.

Seperti halnya saat ini, adanya wabah Corona Virus disease 19 (Covid-19) yang menjadi pandemi dalam beberapa bulan ini sangat berdampak massif pada pengelolaan desa agrowisata ini. Pandemi Covid-19 yang telah ditetapkan sebagai keadaan darurat wabah nasional yang menyerang Indonesia sesuai dengan Keputusan Presiden (KEPPRES) No. 12 Tahun 2020 tentang Penetapan Bencana Non alam Penyebaran Corona Virus Disease 2019 (COVID-19).

\section{Gambar 2. Data Persebaran Covid-19 Kabupaten Tulungagung 2021}

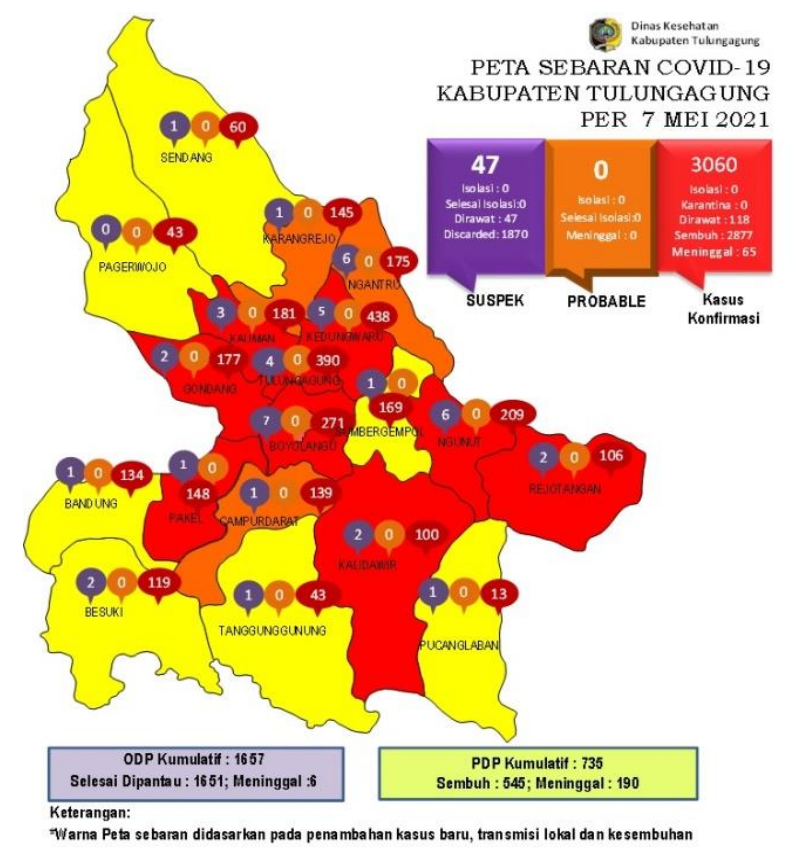

Wabah Covid-19 yang menjangkit hampir di seluruh wilayah Indonesia dan penyebarannya terhitung cepat dan merupakan virus yang mematikan. Tidak terkecuali Kabupaten Tulungagung yang menjadi salah satu kota yang terdampak Covid-19. Dampak virus corona begitu besar, serta bersifat global, dan massif yang mempengaruhi berbagai macam sektor bukan hanya kesehatan, namun juga mempengaruhi aktivitas ekonomi, politik, pemerintahan, pendidikan, dan lainnya. ${ }^{21}$ Termasuk pariwisata, sektor pariwisata adalah salah satu yang terdampak pandemi Covid-19. Maka dari itu sektor wisata perlu dibenahi setelah adanya pandemi karena

\footnotetext{
${ }^{21}$ Darwin Tuwu, "Kebijakan Pemerintah Dalam Penanganan Pandemi Covid-19," Journal Publicuho 3, no. 2 (2020): 269.
} 
pariwisata merupakan sebuah jalan bagi perbaikan ekonomi Indonesia setelah pandemi.

Satu diantara bidang pariwisata yang terdampak oleh pandemi Covid-19 adalah Agrowisata Belimbing di Desa Moyoketen Kecamatan Boyolangu Kabupaten Tulungagung yang merupakan salah satu pariwisata berbasis desa, pihak pengelola perlu menerapkan langkah strategis serta cara yang cepat dan tepat sehinngga proses jalannya Desa Agrowisata ini dapat tetap bertahan dan berjalan. Di dukung oleh pernyataan penelitian ${ }^{22}$ dengan hasil penelitian beberapa upaya strategi terus dilakukan agar industri ini tetap eksis di masa pandemi, antara lain promo massiv, via media sosial, dan tetap menerapkan protokol kesehatan agar para pengunjung aman yang nyaman serta mengikuti uji sertifikasi CHSE (cleanliness, health, safety, environment) dari Kementrian Pariwisata Ekonomi Kreatif. Perubahan dan perancangan langkah yang diambil dapat sangat berpengaruh pada jalannya organisasi agar nantinya dapat dijalankan seefektif dan seefisien mungkin dalam pencapaian tujuan.

Berdasarkan hasil wawancara yang diperoleh dan hasil pengamatan dari peneliti, terdapat kendala yang dialami oleh pihak agrowisata belimbing Desa Moyoketen Kecamatan Boyolangu Kabupaten Tulungagung dalam pengembangan usahanya, yaitu :

1. Minimnya kreatifitas dan inovasi dari sumber daya manusia.

Kendala yang dihadapi ini seperti kurangnya berinovasi dalam pengelolaan buah belimbing sebagai bahan dasar untuk dijadikan olahan makanan, minuman, dan olahan lainnya. Upaya yang dilakukan pemilik yaitu dengan memberikan pelatihan kepada masyarakat terkait pengolahan makanan yang berbahan dasar buah belimbing. Dengan adanya pelatihan pengelola agrowisata tidak hanya menjual buah belimbingnya saja akan tetapi bisa mengolahnya menjadi makanan yang lebih menarik dan memiliki harga jual yang lebih tinggi.

2. Penurunan Pengunjung dan pendapatan Agro belimbing Moyoketen.

Adanya wabah pandemi Covid-19 menyebabkan area wisata tidak diperbolehkan untuk beroperasi. Hal tersebut menyebabkan pengunjung menjadi berkurang dan tidak seperti sebelumnya. Penurunan pengunjung secara tidak langsung akan menguranngi jumlah pemasukan di Agro Belimbing Desa Moyoketen Kecamatan Boyolangu Kabupaten Tulungagung ini. Sistem dana yang seharusnya memiliki dana khusus untuk pengelolaan Agrowisata terpaksa dialihkan untuk penanggulangan Covid-19 yang mengakibatkan kurangnya pemasukan dana untuk agrowisata sebagai dana operasional guna pengembangan program.

\footnotetext{
${ }^{22}$ Masduki, Ida Mursidah, dan Jamaluddin, "Strategi Pengembangan Potensi Wisata Pantai Anyer Provinsi Banten pada Masa Pandemi Covid-19," Jurnal Ekonomi Bisnis Indonesia 15, no. 2 (2020): 76 87.
} 
3. Perbaikan beberapa fasilitas untuk pengunjung belum dilakukan.

Masih terdapat beberapa tempat duduk yang sudah rusak sehingga membuat pengunjung kurang nyaman. Beberapa fasilitas yang dirasa masih kurang dalam menunjang berjalannya agrowisata ini diakibatkan juga karena dampak Covid-19 yang mempenaruhi penundaan pembangunan fasilitas tambahan di wisata ini. Upaya yang dilakukan ialah meningkatkan fasilitas untuk menarik perhatian pengunjung dan memberikan kenyamanan bagi pengunjung, seperti menyediakan spot foto untuk menarik minat pengunjung.

Dari beberapa upaya yang dilakukan, pihak agro blimbing juga tetap menggunakan beberapa strategi diantaranya :

\section{Pemasaran dilakukan secara online}

Di masa pandemi Covid-19 jumlah pengunjung di agrowisata belimbing mengalami penurunan bahkan pengunjungpun tidak diperbolehkan mengunjungi tempat wisata tersebut selama 1 tahun silam. Hal tersebut mengakibatkan penurunan jumlah penjualan buah belimbing. Sehingga pemilik agrowisata belimbing memiliki strategi dalam meningkatkan jumlah penjualan yaitu dengan memasarkan secara online kepada beberapa komunitas yang ada diberbagai daerah. Seperti komunitas ibu PKK, komunitas chinise dan lain-lain.

Pemasaran secara online pada saat ini sangat membantu para pelaku usaha dalam memperluas pasar bagi produk mereka, apalagi saat ini pasar online dapat dengan mudah diakses melalui aplikasi gawai, sehingga membuat mangsa pasar serta mobilitasnya semakin cepat.

\section{Mengutamakan kualitas produk}

Di masa pandemi ini pemilik sangat memperhatikan kualtitas produknya dengan cara mensterilkan wadah untuk menjaga kebersihan produk. Pemilik tidak menghiraukan pesaing di luar terkait harga, karena pemilik memperhatikan kualitas produk dan mempertahankan harga jual. Di sisi lain pemilik juga memperhatikan kepercayaan pembeli dengan cara melakukan pembelian sistem bayar ditempat.

3. Mengolah belimbing menjadi sebuah produk

Penerapan strategi lain yang dilakukan oleh Agro Belimbing Desa Moyoketen Kecamatan Boyolangu Kabupaten Tulungagung saat ini yaitu memaksimalkan hasil produk belimbing tetapi dengan pengeluaran yang minimal. Penekanan jumlah biaya operasional merupakan langkah yang efektif untuk dilakukan saat ini dari segi pengelolaan wisata maupun pembuatan produk olahan. Pengelolaan produk belimbing ini masih memiliki konsep yang sama dilakukan seperti pada masa sebelum pandemi Covid-19, pengelolaan produk belimbing ini dilakukan oleh IbuIbu warga sekitar Desa Moyoketen sendiri. Pengelolaan produk buah belimbing ini akan menghasilkan beberapa produk olahan seperti dodol belimbing, selai belimbing, sari belimbing serta keripik belimbing. 
Pengelolaan produk olahan buah belimbing ini dimaksudkan guna memaksimalkan hasil panen buah belimbing dari Kebun Belimbing, selain buahnya dijadikan obek wisata yang dapat dipetik langsung oleh wisatawan, buah belimbing juga dapat dimaksimalkan pengelolaannya agar lebih mengenalkan bahwa buah belimbing tidak hanya dapat dimakan langsung melainkan juga dapat diolah. Hal ini dilakukan sebagai langkah untuk memaksimalkan program agrowisata ini agar dapat tetap berjalan secara maksimal dikarenakan dalam pengelolaan fasilitas wisata di agrowisata ini sendiri sampai saat ini masih belum lengkap. Pada pengolahan produk belimbing ini pun masih belum sepenuhnya maksimal. Pengelolaan pemasaran yang dilakukan oleh pihak agro belimbing belum dirasa cukup luas dan masih mengandalkan pemasaran secara manual sedangkan teknik pemasaran secara online telah berkembang begitu pesat. Terhitung sejak pandemi Covid-19 menyebar ke seluruh dunia, perilaku masyarakat untuk melakukan kegiatan belanja online mengalami kenaikan.

Pada beberapa produk olahan belimbing seperti sari belimbing hanya dipasarkan kepada beberapa kolega, teman ataupun seseorang yang memesan produk olahan buah belimbing tersebut. Sedangkan dengan olahan lain seperti dodol belimbing dan selai belimbing baru menginjak pasar hingga ke Kota Kediri dan Blitar saja belum meluas ke berbagai kota yang lain.

\section{Melakukan kerjasama dengan pemerintah}

Banyaknya pesaing di kawasan agro belimbing, menjadikan pemilik agrowisata belimbing tidak hanya mengembangkan tanaman belimbing tetapi juga mengembangkan tanaman berbagai jenis jambu yang berada di kawasan agro wilis dengan melakukan kerjasama bersama pemerintah.

Pemilik dan pemerintah melakukan kerjasama yang mana pihak pemerintah menyediakan lahan untuk ditanami tanaman jambu. Dalam pengelolaannya, pemilik menawarkan kepada masyarakat untuk ikut serta dalam penanaman kebun jambu. Maka dari itu pemilik memberi kontrubusi kepada masyarakat dengan sistem bagi hasil. Bagi hasil dalam hal ini dimaksudkan sebagai pembagian hasil untuk orang yang mengolah atau menanami tanah dari yang dihasilkannya seperti setengah, sepertiga atau lebih dari itu berdasarkan perjanjian kedua belah pihak (petani dan pemilik tanah). Dalam pelaksanaan perjanjian, untuk menjaga silaturrahim dan kepercayaan antara kedua belah pihak maka harus dilakukan dengan perjanjian secara tertulis dan juga untuk menjaga agar tidak ada kesalah pahaman antara kedua belah pihak. Sebagaimana dijelaskan dalam QS. Al- Baqarah ayat 282 sebagai berikut:

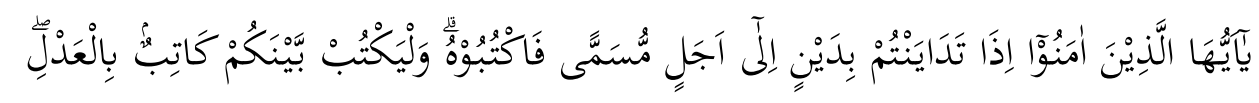

Artinya: "Wahai orang-orang yang beriman! Apabila kamu melakukan utang piutang untuk waktu yang ditentukan, hendaklah kamu menuliskannya. 
Dan hendaklah seorang penulis di antara kamu menuliskannya dengan benar.

Berdasarkan data primer dan sekunder yang diperoleh dari observasi dan wawancara, dapat ditentukan strategi kebijakan berkelanjutan dengan hasil analisis SWOT, yaitu (1) mengidentifikasi faktor kekuatan yang dimiliki agrowisata baik internal maupun eksternal dan (2) mengidentifikasi faktor peluang dan ancaman terhadap agrowisata buah belimbing. Faktor eksternal meliputi faktor wilayah lingkungan sekitar agrowisata. Faktor tersebut terdiri dari dua aspek, yaitu faktor peluang dan ancaman (treaths). Faktor peluang meliputi media informasi untuk memasarkan agrowisata, dukungan masyarakat sekitar, perluasan-perluasan wilayah pemasaran. Berdasarkan data primer penelitian dapat dilihat hasil analisis SWOT pada tabel berikut ini:

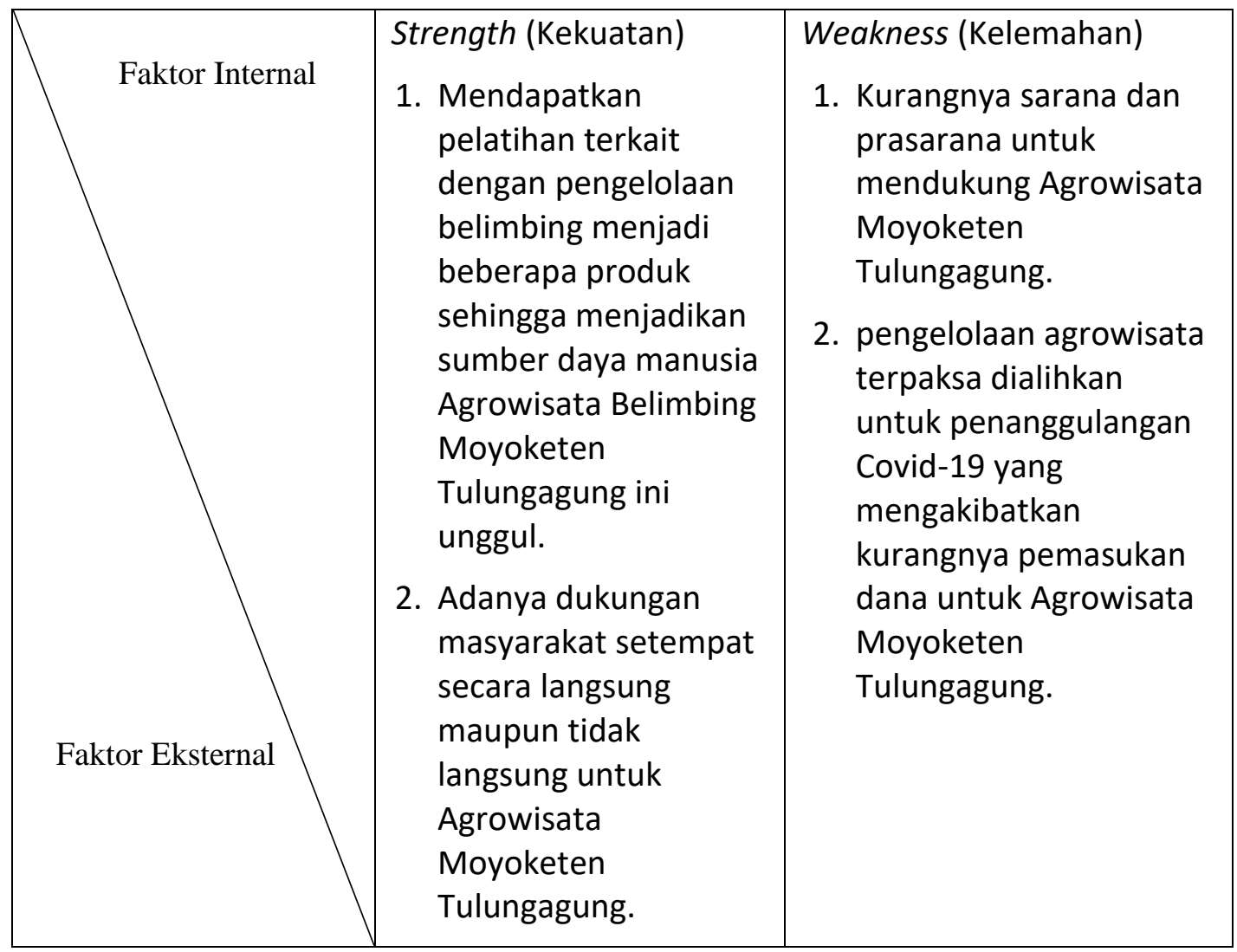




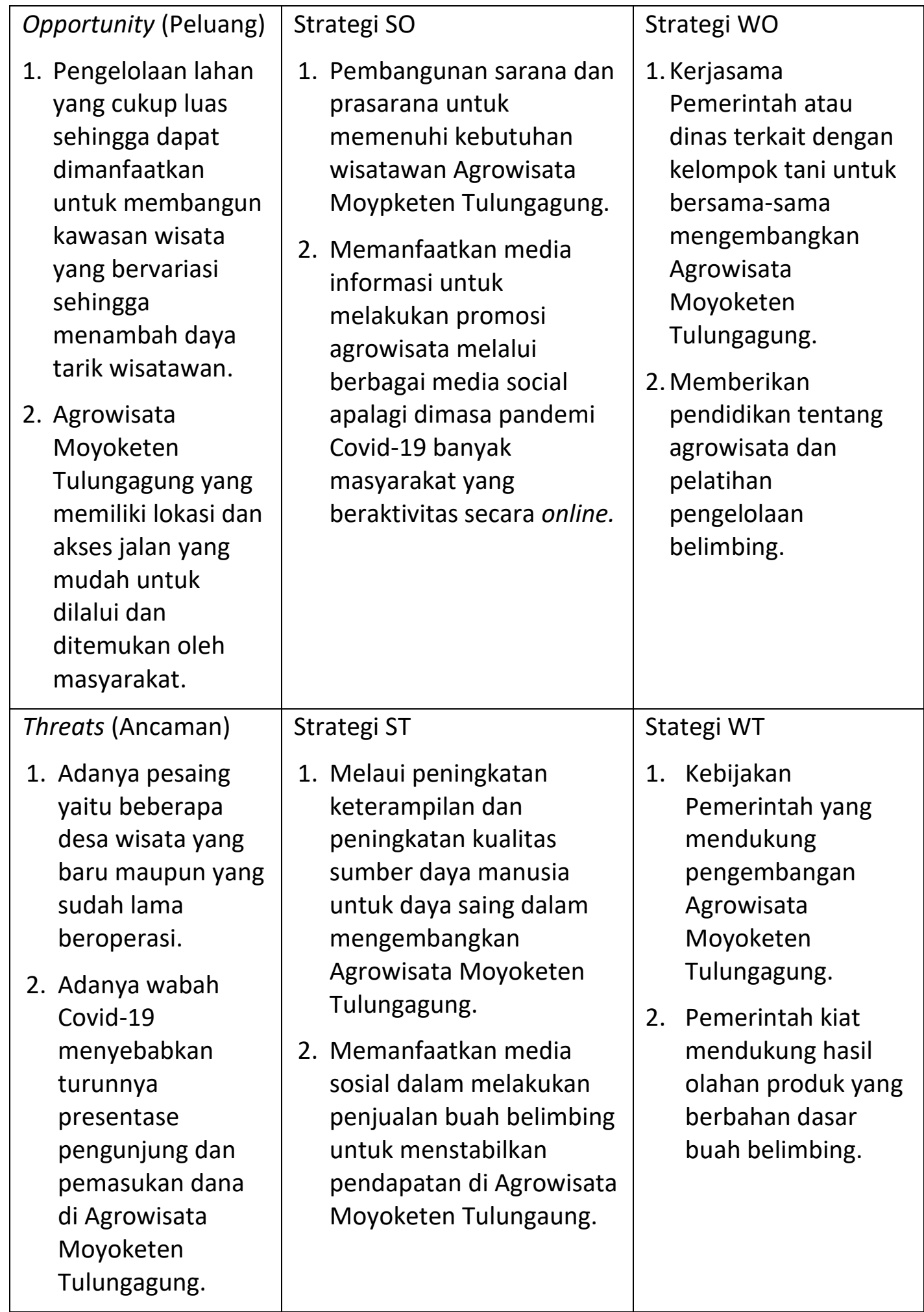

Adapun hasil simpulan pada tabel SWOT di atas yaitu, pertama terkait dengan formulasi strategi yang dilakukan oleh agro belimbing Desa Moyoketen dalam pengelolaan Agrowisata petik belimbing dalam menghadapi pandemi Covid-19 yang berpengaruh pada jalannya wisata dengan mempertimbangkan berbagai faktor 
eksternal organisasi yaitu opportunities (peluang) yaitu Agrowisata Moyoketen yang memiliki lokasi dan akses jalan yang mudah untuk dilalui dan ditemukan oleh masyarakat, sehingga memudahkan dalam pencarian serta pengelolaan lahan yang cukup luas sehingga dapat dimanfaatkan untuk membangun kawasan wisata yang bervariasi sehingga menambah daya tarik wisatawan. Selain itu wisata ini juga telah diliput oleh beberapa media yang menghasilkan feedback yang baik terhadap Desa Agrowisata ini. Sedangkan untuk threats (ancaman) dalam hal ini yaitu adanya pesaing yaitu beberapa desa wisata yang baru maupun yang sudah lama beroperasi mengakibatkan timbulnya ancaman terkait dengan daya saing yang semakin besar ditambah lagi dengan wabah Covid-19 yang akhirnya membuat Agrowisata Belimbing Moyoketen mengalami penurunan presentase pengunjung. Pembatasan kegiatan yang dihimbau oleh pemerintah menyebbkan masyarakat masih enggan untuk melakukan kunjungan wisata secara bebas.

Sedangkan untuk faktor faktor internal terdiri dari strengths (kekuatan), dalam hal ini yaitu faktor sumber daya manusia yang dimiliki oleh agrowisata belimbing Moyoketen selaku pengelola wisata dapat dikatakan telah mendapatkan pelatihan terkait dengan pengelolaan belimbing menjadi beberapa produk sehingga menjadikan sumber daya manusia Agrowisata Belimbing Moyoketen ini unggul, juga produk olahan yang dapat dijual dan dapat dibeli kepada masyarakat sebagai buah tangan. Dalam analisis terkait dengan weakness (kelemahan) yaitu permasalahan pada pengelolaan dana. Sistem dana yang seharusnya memiliki dana khusus untuk pengelolaan Agrowisata terpaksa dialihkan untuk penanggulangan Covid-19 yang mengakibatkan kurangnya pemasukan dana untuk agrowisata sebagai dana operasional guna pengembangan program agrowisata ini. Selain itu juga kurangnya masih minimnya sarana dan prasarana dalam wisata ini juga mendai kelemahan. Beberapa fasilitas yang dirasa masih kurang dalam menunjang berjalannya agrowisata ini diakibatkan juga karena dampak Covid-19 yang mempenaruhi penundaan pembangunan fasilitas tambahan di wisata ini.

\section{Penutup}

Berdasarkan hasil data yang didapatkan dari penelitian terkait dengan analisis strategi pengembangan pariwisata agrowisata belimibing di desa Moyoketen Tulungagung dapat disimpulkan bahwa, strategi yang dilakukan belum maksimal dikarenakan belum adanya tindakan khusus sebagai langkah preventif yang digunakan sebagai strategi untuk menghadapi pandemi Covid-19 dalam pengeloaan wisata yang berdampak pada masih kurangnya pendapatan wisata yang diakibatkan oleh menurunnya jumlah wisatawa sehingga menyebabkan belum adanya pemasukan dana yang signifikan dari agrowisata dan kendala yang dihadapi pengelola di masa pandemi Covid-19 ini yaitu, minimnya kreatifitas dan inovasi dari sumber daya manusia dan upaya yang dilakukan pemilik yaitu dengan memberikan pelatihan kepada masyarakat terkait pengolahan makanan yang berbahan dasar buah belimbing, perbaikan beberapa fasilitas untuk pengunjung belum dilakukan. Selanjutnya strategi yang harus dilakukan oleh pengelola antara lain, memasarkan 
produk secara online di media sosial untuk menstabilkan pendapatan, mengutamakan kualitas produk untuk menjaga kepercayaan konsumen, mengolah belimbing menjadi sebuah produk, melakukan kerjasama dengan pemerintah.

Bagi peneliti selanjutnya, penelitian ini bisa digunakan sebagai bahan perbandingan dan referensi penelitian. Diharapkan peneliti selanjutnya bisa lebih banyak data yang mendukung lalu memperluas cakupan penelitian, lokasi dan juga penerapan analisis yang lainnya sangat diharapkan. Oleh karena itu penelitian ini masih perlu dikembangkan kembali.

\section{DAFTAR PUSTAKA}

Abdullah Amrin, Strategi Pemasaran Asuransi Syariah. Jakarta: Grasindo, 2007.

Amar?]s, Innaka Putri Islami. "Analisis Kendala Dan Alternatif Pembelajaran Biologi Pada Masa Pandemi Covid 19 Di SMA Swasta Yapim Taruna Dolok Masihul." Universitas Islam Negeri Sumatera Utara, 2020.

Anoraga, Panji. Manajemen Bisnis. Jakarta: Rineka Cipta, 2004.

Besra, Eri. "Potensi Wisata Kuliner Dalam Mendukung Pariwisata Di Kota Padang." Jurnal Riset Akuntansi dan Bisnis 12, no. 1 (2021): 11.

Budio, Sesra. "Strategi Manajemen Sekolah." Jurnal Menata 2, no. 2 (2019): 56-72.

Centre, L. I. "Econstor," 2011.

Direktorat Pengembangan Kawasan Khusus dan Tertinggal. Tata Cara Perencanaan Pengembangan Kawasa untuk Percepatan Pembangunan Daerah. Bappenas, 2004.

Fitriana, Evi. "Strategi Pengembangan Taman Wisata Kum Kum Sebagai Wisata Edukasi Di Kota Palangkaraya." Jurnal Pendidikan Geografi 23, no. 2 (2018): 102.

Gunawan, Anita Sulistiyaning, Maria Goretti, dan Wi Endang. "Analisis Pengembangan Pariwisata Terhadap Sosial Ekonomi Masyararakat." Jurnal Administrasi Bisnis (JAB) 32, no. 1 (2016): 2.

Hidayat, Muhammad Rifqi, Rusdiana Rusdiana, dan Parman Komarudin. "Strategi Pendidikan Kewirausahaan Di Sekolah Dasar Alam Muhammadiyah Banjarbaru." AdBispreneur: Jurnal Pemikiran dan Penelitian Administrasi Bisnis dan Kewirausahaan 6, no. 2 (23 November 2021): 125-38. https://doi.org/10.24198/adbispreneur.v6i2.31144.

Itamar, Hugo. "Strategi Pengembangan Pariwisata di Kabupaten Tana Toraja." Jurnal Ilmu Pemerintahan 7, no. 2 (2014): 91-108.

Jaelani, Abdul Kadir. "Pengembangan Destinasi Pariwisata Halal Pada Era Otonomi Luas di Provinsi Nusa Tenggara Barat." Jurnal Pariwisata 5, no. 1 (2018): 5667.

Karyono, Hari. Kepariwisataan. Jakarta: PT. Remaja Rosdakarya, 1997.

Kepariwisataan. "Undang-undang Republik Indonesia No 10 Tahun 2009 Tentang Kepariwisataan Pasal 1 ayat 5," 2009. 
Kurniati, Desna. "Potensi Pengembangan Agrowisata Sebagai Kawasan Eduwisata Lokal Di Agrowisata Cilangkap Jakarta Timur." universitas Islam Negeri Syarif Hidayatullah Jakarta, 2015.

Lutpi, Hakkiatul. "ANALISIS TINGKAT PARTISIPASI MASYARAKAT DALAM PENGEMBANGAN PARIWISATA PANTAI DI KECAMATAN JEROWARU." Jurnal Program Studi Pendidikan Ekonomi 8, no. 3 (2016): 1-10.

Masduki, Ida Mursidah, dan Jamaluddin. "Strategi Pengembangan Potensi Wisata Pantai Anyer Provinsi Banten pada Masa Pandemi Covid-19." Jurnal Ekonomi Bisnis Indonesia 15, no. 2 (2020): 76-87.

Nimran, Umar. Perilaku Organisasi. Surabaya: Citra Media, 1997.

Nur?aini, Fajar. Teknik Analisis Swot. Jakarta: Anak Hebat Indonesia, 2016.

Oktaviyani, Tety Eka. "Analisis Strategi Pemasaran Terhadap Pengelolaan Wisata Telaga Sarangan Di Kabupaten Magetan." Institut Agama Islam Negeri Ponorogo, 2020.

Prihanta, Wahyu, Amir Syarifuddin, dan Ach. Muhib Zainuri. "Pembentukan Kawasan Ekonomi Melalui Pengembangan Ekowisata Berbasis Masyarakat." Jurnal Dedikasi 14 (2017): 73-84.

Raco, J.R. Metode Penelitian Kualitatif Jenis, Karakteristik dan Keunggulannya. Jakarta: Grasindo, 2013

Rafi[?] Setia, 2001.

Tuwu, Darwin. "Kebijakan Pemerintah Dalam Penanganan Pandemi Covid-19." Journal Publicuho 3, no. 2 (2020): 269. 